\title{
NÁZOR REJSTŘÍKOVÝCH SOUDU゚: ODBOROVÁ ORGANIZACE SPOLKEM, ČI RADĚJI NE?
}

\author{
MARTIN ŠTEFKO*
}

\begin{abstract}
Registrar's Opinion on Trade Union's Legal Status
This paper deals with registrar's standards procedure when they are required to register a trade union organisation into the Registry of Associations. There is an ongoing discussion on trade union's legal status among scholars, practitioners and even judges. Some claim they are associations, but they are opposed by trade union's establishment and few registrars. If this happens those trade unions are denied the entry to the register, what has been meanwhile overruled by upper courts, or they are required to change their name deleting the term "association" thereof.
\end{abstract}

Keywords: Trade Union; Association; Registry of Associations; Registrar Court

Klíčová slova: odborová organizace; spolek; spolkový rejstř́k; rejstř́ikový soud

DOI: $10.14712 / 23366478.2019 .11$

\section{ÚVOD}

České kolektivní pracovní právo bylo nuceno se při rekodifikaci soukromého práva dokončené v roce 2014 vypořádat s pojmovým uchopením odborové organizace jako konkrétního typu právnické osoby. Názory byly různé a diskuze poměrně bouřlivé. S jistým odstupem se do řešení tohoto problému zapojila též judikatura, a to včetně nejvyšších článkủ soudní soustavy. Př́nos judikatury byl a je rozhodující, bohužel praxe rejstř́ikových soudů zatím zcela jednotná není. Některé odborové organizace mají v názvu zmíněno, že jsou spolkem, jiné nikoliv. Dle stavu zápisu ve spolkovém rejstř́íku spíše převažují ty odborové organizace, které se jako spolek v názvu neidentifikují.

Cílem tohoto článku je poukázat na pozadí různých názorových proudů a za využití detailního výzkumu stavu zápisů ve spolkovém rejstř́ku na teoretické i praktické pojmové uchopení odborové organizace jako základní figury pracovního práva. Za tím účelem bude proveden nejprve historický vhled do zkoumané problematiky, aby následně došlo $\mathrm{k}$ analýze právní úpravy, názorů doktríny a soudobé rejstř́íkové praxe.

\footnotetext{
* Autor působí jako docent na katedře pracovního práva a práva sociálního zabezpečení a je rovněž advokátem Kocián Šolc Balaštík, advokátní kancelář, s.r.o.
} 


\section{HISTORICKÝ EXKURZ}

Pojem odborové organizace byl vždy poněkud nejasný. ${ }^{1}$ Souvisí to jednak s jeho živelným vývojem v 19. století, jednak se státní represí, k jejímuž postupnému uvolnění dochází v českých zemích teprve po roce $1867 .^{2}$ Identifikující pro tato společenstva byl především materiální prvek, řečeno dnešní pracovněprávní terminologií: sdružování za účelem vzájemného posílení sociální bezpečnosti. Jedná se v podstatě o starou myšlenku dělnické participace na ř́zení podniku, která byla v 19. století zastávána ovšem pouze několika socialistickými filozofy a sociálně demokratickým hnutím. ${ }^{3} \mathrm{~K}$ její realizaci došlo poprvé ve Velké Británii u obecních podniků a v Rusku (zákon č. 23. 4. 1917). Po první světové válce jisté formy zaměstnanecké participace legislativně podchytilo též Rakousko, ČSR a Německo. V té nejširší podobě, jak ji známe dnes, tedy jako povinné personální informace a konzultace, kolektivní vyjednávání, zaměstnanecké rady, spolurozhodování v podnikových radách, účast v řídících orgánech podniku a samořízení, však byla upravena teprve po druhé světové válce, a to takřka výlučně veřejnoprávními předpisy.

Odborová organizace tedy vždy ze své podstaty bojovala a bojuje za ochranu a zlepšení pracovních podmínek zaměstnanců. Je tak význačným prvkem demokratizmu v pracovním právu, jakož i projevem zaměstnanecké a lidské solidarity. Za odborové organizace se v souladu s např. čl. 10 Úmluvy Mezinárodní organizace práce č. $87^{4}$ považovaly takové organizace, které měly za cíl podporovat a hájit zájmy zaměstnanců, a jejich cílem bylo a je vytváření podmínek pro uplatňování pracovních, ekonomických, mzdových, sociálních a kulturních zájmů svých členů, zastupování členů při jednáních se zaměstnavatelem, spolurozhodování o tvorbě a rozdělování finančních prostředků a vedení kolektivního vyjednávání se zaměstnavatelem.

Představené materiální pojetí je ovšem vysoce subjektivní, a proto obtížně prokazatelné. Pro zaměstnavatele jako sociálního partnera i členy předmětné odborové organizace je často velmi obtížně seznatelné, zda určité konkrétní kroky odborové organizace jsou opravdu v zájmu zaměstnanců. Státní orgány tomuto faktu čelily v různých dobách různě. Zmínit lze např. kroky nacistické okupační moci, která centralizovala zástupce zaměstnanců do Národní odborové ústředny zaměstnanecké (NOÚZ), ${ }^{5}$ kterou pak následně využívala $\mathrm{k}$ propagandistickým účelům. $\mathrm{V}$ této souvislosti lze zmínit ust. $§ 1$ vládního nařízení o úpravě poměrů v odborových organizacích zaměstnaneckých ze dne 14. srpna 1941, č. 347 Sb., dle kterého o tom, zda je zaměstnanecká organizace organizací odborovou, rozhodoval úr̆ad dle své úvahy.

1 K platnému vymezení odborové organizace především J. Pichrt v komentári $\mathrm{k}$ ust. § 286. In: BĚLINA DRÁPAL a kol. Zákoník práce, komentáŕ. 2. vyd. Praha: C. H. Beck, 2014, s. 1112.

2 Viz např. MALÝ, K. Policejní a soudní perzekuce dèlnické třídy v druhé polovině 19. stoleti v Čechách. 1. vyd. Praha: Academia, 1967. 282 s.

3 TOMEŠ, I. Zaměstnanecká participace na ř́zení podniku. Právník. 1991, č. 5, s. 369.

4 Úmluva o svobodě sdružování a ochraně práva odborově se organizovat (sdělení federálního ministerstva zahraničních věcí č. 489/1990 Sb.)

5 K tomu zejména PICHRT, J. In: BĚLINA, M. a kol. Pracovní právo. 6. vydání. Praha: C. H. Beck, 2014, s. 146. 
Tento materiální znak byl akceptován též judikaturou. ${ }^{6}$ Nutno ovšem dodat, že ochranou a hájením zájmů zaměstnancủ byly pověřeny v minulosti též jiné orgány ${ }^{7}$ a že jednoznačné vítězství odborové organizace $\mathrm{v}$ tomto směru jako univerzálního zástupce zaměstnanců nebylo ani zdaleka spontánní. ${ }^{8}$

Pokud jde o úpravu formálního znaku odborové organizace v recentní historii, tedy její právní osobnosti, pak lze především poukázat na ust. § 1 zákona č. 144/1946 Sb., o jednotné odborové organizaci, jež na dlouho spojilo odborové organizace zř́zené ve formě spolku s názvem Revolučním odborovým hnutím. ${ }^{9}$

Právní úprava odborové organizace pokročila do nové fáze zákonem č. 68/1951 Sb., o dobrovolných organizacích a shromážděních. ${ }^{10}$ Předmětný zákon byl založen na povolovacím principu, což samožrejmě neuniklo pozornosti Mezinárodní organizace práce. Vzhledem k jejím námitkám, že zákon č. 68/1951 není v souladu s Úmluvou o odborové svobodě a ochraně odborového práva z r. 1948, byl tento změněn zákonem č. 74/1973 Sb. s účinností od 3. července 1973 tak, že ustanovení $§ 1$ až 5 ,se nevztahují na odborové organizace“.11

Předposlední vývojovou fází byla úprava v usnesení IV. všeodborového sjezdu o závodních výborech základních organizací Revolučního odborového hnutí, které bylo publikováno jako př́loha zákona č. 37/1959 Sb. o postavení závodních výborů základních organizací Revolučního odborového hnutí. ${ }^{12}$ Dle bodu 24 usnesení IV. všeodborového sjezdu o závodních výborech základních organizací Revolučního odborového hnutí (ROH) byl závodní výbor prohlášen prostě za právnickou osobu. ${ }^{13}$ Ústřední rada odborů mohla dále prohlásit za právnické osoby i jiné odborové orgány či účelová zaří-

6 Usnesení Krajského soudu Praha č. j. 30 Co 116/2003-06-16 in: Bulletin Advokacie. 2003, č. 10, s. 60. Dále např. rozsudek Nejvyššího soudu ze dne 28. května 2013, sp. zn. 21 Cdo 390/2012.

7 K tomu např. zákon z 25. února 1920, č. 144 Sb. z. a n., o závodních a revírních radách při hornictví, zákon ze dne 12. srpna 1921, č. 330 Sb., o závodních výborech nebo Dekret prezidenta republiky č. 104/1945 Sb. o závodních a podnikových radách.

8 Spolu s nástupem detailního direktivního řízení dochází postupně k umlčování závodních a podnikových rad a k jejich nahrazování jednotnou odborovou organizací. Formálně se tak stalo zákonem č. 37/1959 Sb., o postavení závodních výborů základních organizací Revolučního odborového hnutí, který zrušil dekret prezidenta republiky č. 104/1945 Sb., o závodních a podnikových radách. K tomu např. KALENSKÁ, M. Pracovni právo v tržním hospodářství, s. 705. Dále PICHRT, J. In: BĚLINA, M. a kol. Pracovní právo. 6. vyd. Praha: C. H. Beck, 2014, s. 354.

9 Zákon č. 144/1946 Sb., o jednotné odborové organizaci posléze našel posléze svoji oporu v Ústavě 9 . května. K tomu srov. ust. $\S 25$. Ústř̌ední rada odborů byla nicméně pověřena k převzetí všech odborových svazů a spolků v českých zemích již 6. května 1945 Českou národní radou. Výnos Ministerstva vnitra č. IV-311119/5-45 ze dne 19. května 1945 pak označil ÚRO za právního nástupce všech odborových organizací.

10 Zde se jednak ,jednotná odborová organizace“ uvádí jako př́klad dobrovolné organizace (v ust. § 1), jednak se Revoluční odborové hnutí prohlašuje za organizaci podle tohoto zákona (ust. § 5). Zákon č. 68/1951 Sb. upravil dobrovolné organizace jako formu dobrovolného sdružování s posláním směřujícím především $\mathrm{k}$ upevnění lidově demokratického zřízení a $\mathrm{k}$ podpoře úsilí o výstavbu socialismu. $\mathrm{V}$ důsledku této kvalitativní změny v právní úpravě dobrovolného sdružování bylo těžiště sdružování z oblasti spolků přeneseno do většinou celostátních masových „dobrovolných“ organizací. Tak na jedné straně rostl počet dobrovolných organizací podle zákona č. 68/1951 Sb., na druhé straně pronikavě poklesl počet spolků.

11 Srov. čl. I zákon č. 74/1973. Sb.

12 PICHRT, J. In: BĚLINA, M. a kol. Pracovní právo. 6. vyd. Praha: C. H. Beck, 2014, s. 354.

13 Judikatura označení právnická osoba specifikovala na právnickou osobu socialistického charakteru, která je současně socialistickou organizací. K tomu rozhodnutí Nejvyššího soudu ze dne 31. 10. 1962, sp. zn. 6 Cz 29/62. 
zení ROH. ${ }^{14}$ Dle bodu 18 předmětného usnesení současně platilo, že stanovy odborové organizace a opatření podle nich učiněná nepodléhají schválení ani evidenci státních orgánů. K zajištění jednotného výkladu a provádění byla autorizována Ústřední rada odborů, aby vydala potřebné směrnice. ${ }^{15}$

Zákon č. 37/1959 Sb. byl zrušen čl. III bodem 1 zákona č. 3/1991 Sb., kterým se mění a doplňuje zákoník práce s účinností k 1. 2. 1991. Novou komplexní úpravu přinesl od 1. 5. 1990 zákon č. 83/1990 Sb., o sdružování občanů. Důvody jeho přijetí jsou pregnantně vymezeny $\mathrm{v}$ důvodové zprávě. Od přijetí výše zmíněného zákona č. 74/1973 Sb. nebyly vznik, působení a zánik odborových organizací nijak právně upraveny, což však vzhledem k tehdejším mocenským poměrům nevadilo, nebot' stejně nové odborové organizace vznikat nemohly. ${ }^{16}$ Proto bylo namístě výslovně v ust. § 2 zákona o sdružování občanů dovolit zakládat odborové organizace. Protože registrace měla být pouze deklaratorním rozhodnutím (správní orgán měl pouze zjišt’ovat, zda sdružení splňuje předpoklady stanovené zákonem), měl se tento režim aplikovat též na vznik odborových organizací. Zákonodárce nicméně nakonec od této úpravy ustoupil a pro vznik odborové organizace raději zásadní výjimky upravil zákonem č. 300/1990 Sb. Ten s účinností k 19. 7. 1990 přinesl zvláštní úpravu v ust. § 9a založenou na evidenčním principu. Tato úprava pak s jedinou dílčí změnou ${ }^{17}$ vydržela až do svého zrušení občanským zákoníkem. ${ }^{18}$

\section{POJMOVÉ ZAŘAZENÍ ZÁKLADNÍ ODBOROVÉ ORGANIZACE V PLATNÉ ÚPRAVĚ}

Občanský zákoník v části páté hlavě druhé příznačně nazvané „Ustanovení přechodná a závěrečná“ obsahuje v ust. § 3046 obč. zák. pravidlo, které je nutno aplikovat beze zbytku, nikoliv pouze přiměřeně. Dle předmětného ustanovení platí, že odborová organizace a jejich organizační jednotky evidované podle zákona č. 83/1990 Sb., o sdružování občanů, ve znění pozdějších předpisů se považují za odborové organizace a jejich pobočné organizace podle občanského zákoníku. Z ust. § 3041 odst. 1 první věty obč. zák. pak vyplývá, že právní povaha právnických osob upravených občanským zákoníkem se řídí ustanoveními občanského zákoníku od dne 1. 1. 2014. Ve shodě s tímto někteří autoři skutečně považují odborové organizace ve smyslu terminologie občanského zákoníku za spolky. ${ }^{19}$

14 Toto oprávnění vyplývalo dle judikatury již z ust. § 2 bod 2 zákona č. 144/1946 Sb. K tomu viz rozhodnutí krajského soudu v Ostravě z 12. ř́ijna 1952, sp. zn. 10 Ok 199/52.

15 Usnesení IV. všeodborového sjezdu o závodních výborech základních organizací.

16 Tisk 281, FS ČSSR, V. volební období, 1990, čl. I, tisk je dostupný online na: <http://www.psp.cz/eknih /1986fs/tisky/t0281_00.htm> [cit. 15.2.2015].

17 Provedenou zákonem č. 227/2009 Sb.

18 Zákon č. 65/1965 zákoník práce ji zachoval v ust. § 279 odst. 4. Dle předmětného ustanovení se zákon č. 37/1959 Sb. spolu s usnesením připojuje jako př́loha k zákoníku práce. Ústava ČSSR v čl. 5 uváděla Revoluční odborové hnutí jako př́klad dobrovolných společenských organizací.

19 K platnému vymezení odborové organizace především J. Pichrt v komentáři k ust. § 286 in: BĚLINA, M. - DRÁPAL, L. a kol. Zákoník práce, komentár̆. 2. vyd. Praha: C. H. Beck, 2014, s. 1112. 
Protože Česká republika ctí své mezinárodní závazky, zejména úmluvy Mezinárodní organizace práce, bylo do občanského zákoníku zařazeno ust. § 3025, z něhož vyplývá, že ustanovení občanského zákoníku o právnických osobách a spolku se použijí na odborové organizace přiměřeně jen $v$ tom rozsahu, $v$ jakém to neodporuje jejich povaze zástupců zaměstnanců podle mezinárodních smluv, kterými je Česká republika vázána a které upravují svobodu sdružování a ochranu práva svobodně se sdružovat. Odborové organizace jsou tedy ust. § 3025 obč. zák. klasifikovány jako právnická osoba-spolek, $\mathrm{s}$ účelově volnějším režimem. ${ }^{20}$ Takto výslovně to stanoví též konsolidovaná důvodová zpráva. ${ }^{21}$ Jako důvod speciálního režimu je v důvodové zprávě uváděna výslovně Úmluva MOP č. 87 o svobodě sdružování a ochraně práva odborově se organizovat, 1948 (č. 489/1990 Sb.). ${ }^{22}$

Občanský zákoník sám používá v ust. § 3046 označení odborová organizace; stejně tak ust. § 26 odst. 1 písm. b) zákona č. 304/2013 Sb., o veřejných rejstřících právnických a fyzických osob, v platném znění rovněž uvádí pojem odborové organizace a zkracuje jej jako spolek. V ust. § 121 zákon č. 304/2013 Sb. se ovšem opět používá pojem odborová organizace.

Odborná literatura po 1. 1. 2014 při označení základní odborové organizace tenduje k označení spolek, ${ }^{23}$ někdy též spolek sui generis. ${ }^{24}$ Další autoři toto označení zcela odmítají a trvají na svébytném pojmu odborová organizace. ${ }^{25}$ Metodika Českomoravské konfederace odborových svazů, kterou můžeme vzít jako př́klad názoru odborových organizací, výslovně pojmovou klasifikaci odborových organizací neprovádí, ${ }^{26}$ na druhou stranu tato odborová centrála svi̊j názor opakovaně jednoznačně vyjádřila v tomto i v ji-

20 Srov. K tomu konsolidovaná důvodová zpráva k NOZ, s. 589, z literatury pak např. VÁCHA, J. Odborové organizace v područí právní úpravy v novém občanském zákoníku. Pracovní právo. 2013, s. 2 dostupné též na: <https://www.law.muni.cz/sborniky/pracpravo2013/files/010.html> [cit. 13. 2. 2016]; dále komentár T. Dvořáka in: ŠVESTKA, J. - DVOŘÁK, J. - FIALA, J. a kol. Občanský zákoník. Komentář. Svazek VI. Praha: Wolters Kluwer, 2014, s. 1332.

21 Konsolidovaná důvodová zpráva k NOZ, s. 589.

22 Konsolidovaná důvodová zpráva k NOZ, s. 589.

23 RONOVSKÁ, K. In: LAVICKÝ, P. a kol. Občanský zákoník I. Obecná část (\$ 1-654). Komentář. 1. vydání, Praha: C. H. Beck, 2014, s. 2307. Dále KOSTADINOVOVÁ, I. Odborová organizace jakožto občanské sdružení alias spolek po rekodifikaci soukromého práva v České republice, dostupný online na: <http:// www.law.muni.cz/sborniky/pracpravo2013/files/011.html > [cit. 15. 5. 2016].

24 Srov. komentář T. Dvořáka in: ŠVESTKA, J., DVOŘÁK, J., FIALA, J. a kol., Občanský zákoník. Komentár̆. Svazek VI. Praha: Wolters Kluwer, 2014, s. 1383, dále VÁCHA, J. Odborové organizace v područí právní úpravy v novém občanském zákoníku. Pracovní právo. 2013, s. 2 dostupné též na: <https://www .law.muni.cz/sborniky/pracpravo2013/files/010.html> [cit. 13. 9. 2016].

25 STRÁNSKÝ, J. - SAMEK, V. - HORECKÝ, J. Nový občanský zákoník a pracovní právo. Praha: Sondy, 2014, s. 67. Srov. však další argumenty J. Pichrta v komentáři k ust. § 286. In: BĚLINA, M. - DRÁPAL, L. a kol. Zákoník práce, komentár̆. 2. vyd. Praha: C. H. Beck, 2014, s. 1113.

$26 \mathrm{~K}$ tomu s. 4 dokumentu dostupného online na: $<$ http://www.google.cz/url?sa=t\&rct=j\&q=\&esrc=s\&source =web \&cd=1\&ved=0CCIQFjAA\&url=http $\% 3$ A \%2F\%2Fvos.cmkos.cz\%2Ffile_download \%2F $1213971989 \% 2$ FMetodika\%2B\%25C4\%258CMKOS $\% 2 B k \% 2 B$ nov $\% 25 \mathrm{C} 3 \% 25 \mathrm{~A} 9 \% 2 \mathrm{~B}$ $\% 25 \mathrm{C} 3 \% 25 \mathrm{BAprav} \% 25 \mathrm{C} 4 \% 259 \mathrm{~B} \% 2 \mathrm{Bpostaven} \% 25 \mathrm{C} 3 \% 25 \mathrm{AD} \% 2 \mathrm{C} \% 2 \mathrm{Bpr} \% 25 \mathrm{C} 3 \% 25 \mathrm{~A} 1 \mathrm{v}$ $\% 2 \mathrm{Ba} \% 2$ Bpovinnost $\% 25 \mathrm{C} 3 \% 25 \mathrm{AD} \% 2 \mathrm{Bodbo}$. doc\&ei=3WHaVNmBPILxUuenhLAO\&usg=AFQjCNF -2AnD6_HrKrt4u4LXwUg6fVnjXA\&bvm=bv.85464276,d.d24> [cit. 10. 2. 2016]. 
ných dokumentech tak, že se jedná o „,právnickou osobu sui generis“. ${ }^{27}$ Dle ČMKOS se ust. § 216 občanského zákoníku na odborové organizace nevztahuje. ${ }^{28}$

Některé svazy se raději ve svých vyjádřeních drží též s odkazem na čl. 20 odst. 1 Listiny základních práv a svobod již zažitého pojmu občanské sdružení. ${ }^{29}$ Návrh zákona o evidenci odborových organizací, pobočných odborových organizací, organizací zaměstnavatelů a pobočných organizací zaměstnavatelů a o změně některých dalších zákonů (zákon o evidenci organizací) ve znění, v jakém byl předložen k projednání Legislativní radě vlády se s ohledem na obecné soukromé právo přidržel označení pobočná odborová organizace a hlavní organizace.

\section{1 ÚMLUVA MOP Č. 87}

Výklad relevantní úmluvy č. 87 ze strany Mezinárodní organizace práce, vyplývá z dokumentu označeného Freedom of Association, Digest of decisions and principles of the Freedom of Association Committee of the Governing Body of the ILO, Fifth (revised) edition (dále ,Digest" ${ }^{6}{ }^{30}$ Relevantní je v této souvislosti zejména část šestá Digest nazvaná „Right of organizations to draw up their constitutions and rules“. Ze závěrů obsažených v této části lze dovodit, že přijetí zákonné úpravy regulující fungování odborové organizace není samo o sobě v rozporu s mezinárodně garantovanou autonomií odborových organizací tvořit vlastní stanovy a pravidla fungování (závěr 370 Digest), pokud je tato úprava obecná. Rozhodování rejstř́k kového soudu při zápisu práv a povinností odborové organizace by tvořily problém pouze tehdy, pokud toto rozhodování bylo mimo diskreční pravomoc tohoto soudního orgánu (závěr 373 Digest).

Podrobná regulace vnitřního fungování odborové organizace je však považovaná za problematickou (závěr 369 Digest), pokud by se nejednalo o toliko formální (minimální) požadavky na podobu tohoto vnitřního fungování (závěr 371 Digest). Regulace vztahů odborových svazů a základních organizací by měla být výjimečná a jako taková použitelná pouze pro neobvyklé př́ípady (závěr 386 Digest). Odborové organizace by navíc $\mathrm{v}$ těchto případech měly mít zachovány všechny možné nástroje obrany proti zásahům do jejich autonomie (závěr 386 Digest).

27 Např. v dokumentu nazvaném Požadavky ČMKOS na změny v oblasti nového soukromého práva (Podklad pro jednání RHSD) ze dne 14. 3. 2014. Dokument je dostupný online na: <http://www.google.cz/ url? sa=t\&rct=j\&q=\&esrc=s\&source=web\&cd=31\&ved=0CB8QFjAAOB4\&url=http\%3A\%2F\%2Fkzps. cz\%2Fwp-content $\% 2$ Fuploads\%2F2014\%2F09\%2Fk-bodu-2-2-pozadavky-cmkos-na-zmeny-v-oblasti-noveho-soukromeho-prava-podklad-pro-rhsd.doc\&ei=73fiVP2aBav-ygOax4Fw\&usg=AFQjCNE9sjTv39BmbLWO11wAcmaLYqCGwQ\&sig2=TMx77tSzcqipQqC0sUt_xQ> [cit. 6. 10. 2016].

28 Ust. § 216 občanského zákoníku zní: „Název spolku musí obsahovat slova „spolek“ nebo ,zapsaný spolek“, postačí však zkratka ,z. s.“"

29 Za všechny např. názor Odborového svazu pracovníků hornictví, geologie a naftového průmyslu <http:// www.google.cz/url? sa=t\&rct=j\&q=\&esrc=s\&source=web\&cd=6\&ved=0CEEQFjAF\&url=http $\% 3 \mathrm{~A} \%$ 2 F\%2Fwww.osphgn.cz\%2Ffile $\% 2$ F 74\%2Fodborova-organizace-v-nove-uprave-soukromeho-prava-a-verejnem-rejstriku-pravnickych-a-fyzickych-osob.doc\&ei=TF_iVPfXLcGBUdSFgtAJ\&usg=AFQjCNEHjB211jd7LSA2MMWjZElsHOc-Ww\&sig2=xVlw2cfNmByqMGM4GW48Qw\&bvm=bv.85970519,d. d24> [cit. 19. 8. 2016].

30 Publikace je dostupná online na: <http://www.ilo.org/wcmsp5/groups/public/---ed_norm/---normes/documents/publication/wcms_090632.pdf $>$ [cit. 11.2.2015]. 


\section{REJSTŘÍKOVÉ SOUDY}

V souvislosti s rejstř́íkovým řízením již sociální partneři učinili poznatky svědčící dle jejich názoru o problematičnosti platné úpravy i její aplikace rejstř́kovými soudy. ${ }^{31}$ Jejich názor podpořilo též Ministerstvo práce a sociálních věcíí ${ }^{32}$ a opakovaný tlak nakonec vyústil v rozhodnutí vlády ze dne 3. listopadu 2014, která usnesením č. 892 uložila ministryni práce a sociálních věcí zpracovat v součinnosti s ministryní spravedlnosti návrh zákona o evidenci odborových organizací a organizací zaměstnavatelů a předložit jej vládě do 31 . prosince $2014 .{ }^{33}$ Návrh zákona přes opakované snahy nakonec schválen nebyl. ${ }^{34}$

I do rejstř́íkového řízení se tak přenesl teoretický problém, zda odborová organizace je či není spolkem. Většina rejstř́kových soudů tuto otázku ponechala na odborové organizaci a respektovala názor navrhovatele. Dle stavu spolkového rejstř́ku lze identifikovat desítky odborových organizací, jejichž názvy nevyhovují ust. § 216 občanského zákoníku a nepoužívají ve svém názvu slovo „spolek“ či identifikační zkratku této právní formy. Na druhou stranu existuje též řada odborových organizací, které se jako spolek výslovně ve svém názvu označují. ${ }^{35}$ Některé odborové organizace jsou dokonce př́mo ve spolkovém rejstř́ku zapsány z hlediska právní formy jako spolek, konkrétně jde např. o Odborový spolek zaměstnanců VOŠ a SŠ Varnsdorf, Karolíny Světlé $2703,{ }^{36}$ Odborový svaz SECURIOS, z. s. ${ }^{37}$ či z judikatury známější Odborová organizace Sluníčko. ${ }^{38}$

Krajský soud v Českých Budějovicích jako zatím jediný zaujal jednoznačný názor, že i když se odborová organizace zapisuje do spolkového rejstř́ku, není spolkem, a proto se jako spolek ani nesmí označovat. Dovolává se přitom ust. § 132 odst. 2 občanského zákoníku, dle kterého: „Název musí odlišit právnickou osobu od jiné osoby a obsahovat označení jeji právní formy. Název nesmi být klamavý. “Ani Krajský soud v Českých Bu-

31 Diskutováno např. na 110. plenárním zasedání schůze RHSD dne 30. června 2014.

32 Srov. materiál připravený Ministerstvem práce a sociálních věcí materiál „Řešení problémů evidence odborových organizací a organizací zaměstnavatelü“, který byl předložen na zasedání 111. Plenární schůze RHSD, konané 28. července. 2014. Dokument je dostupný na: <http://www.ospzv-aso.cz/addons/111\%20RHSD /Reseni-problemu-evidence-odborovych-organizaci-a-organizaci-zamestnavatelu.pdf $>$ [cit. 15. 2. 2018].

33 Meziresortní připomínkové řízení probíhalo ve dnech 27. listopadu až 12. prosince 2014. Bliže viz $<$ https:// apps.odok.cz/kpl-detail?pid=KORN9R9JDXGI > [cit. 15. 2. 2018].

34 Srov. <https://apps.odok.cz/attachment/-/down/IHOAA2PARRUZ> [cit. 7. 10. 2016].

35 Namátkově lze odkázat na spolky: Odborová organizace pracovníkủ Moravské filharmonie Olomouc z. s., vedená u Krajského soudu v Ostravě, sp. zn. L 16440, Odborová organizace zaměstnancủ Fondu dalšího vzdělávání z. s., vedená u Městského soudu v Praze, sp. zn. L 66006, ODBOROVÁ ORGANIZACE KASI z.s. vedená u Krajského soudu v Hradci Králové, sp. zn. L 9964, Odborová organizace JASNÁ CESTA, z.s. vedená u Krajského soudu v Ostravě, sp. zn. L 11330, Nezávislá odborová organizace Fehrer Bohemia, s.r.o. - závod 02, spolek, vedená u Krajského soudu v Ústí nad Labem, sp. zn. L 5777, Nezávislá odborová organizace Fehrer Bohemia, s.r.o. - závod 01, spolek, vedená u Krajského soudu v Ústí nad Labem sp. zn. L 5819, Nezávislá odborová organizace Lesní závod Židlochovice (spolek), vedená u Krajského soudu v Brně sp. zn. L 19965. Jako odborová organizace je zapsán též Spolek hornických důchodců dolu J. Fučík, závodu 4 a 9 u Krajského soudu v Ostravě pod sp. zn. L 4759 a Spolek fanoušků Krotitelů duchů v likvidaci u Městského soudu v Praze, sp. zn. L 69440.

36 Odborová organizace je vedena u Krajského soudu v Ústí nad Labem pod sp. zn. L 9266.

37 Odborový svaz je veden u Městského soudu v Praze pod sp. zn. L 65359.

38 Odborová organizace je vedena u Krajského soudu v Hradci Králové pod sp. zn. L 8297. 
dějovicích však nebyl důsledný a odborové organizace označující se jako spolek zapisuje. Snaží se však zjednat nápravu následně a ukládá odborovým organizacím bliže nespecifikovanou výzvou, aby se podřídily občanskému zákoníku (sic!) a samy podaly návrh na změnu svého názvu, kde již nebude uvedeno, že se jedná o spolek či zapsaný spolek.

Se svým názorem nicméně zatím zůstává Krajský soud v Českých Budějovicích osamocen, nebot' ostatní rejstř́ḱkové soudy, a to konkrétně Městský soud v Praze a Krajské soudy v Hradci Králové, Ostravě a Ústí nad Labem nepovažují za klamavý název odborové organizace obsahující současně identifikaci, že se jedná o odborovou organizaci a spolek. $Z$ výkladové praxe vrchních soudů lze zmínit jedno usnesení, kde rovněž Vrchní soud v Olomouci považuje odborovou organizaci za spolek. ${ }^{39}$ Rozhodovací praxe Vrchního soudu je patrná z př́padu odborové organizace, kde byl její zápis odmítnut a teprve na zásah Vrchního soud v Praze došlo k jejímu zápisu. ${ }^{40}$

Přinejmenším z procesního hlediska lze předpokládat, že názor Krajského soudu v Českých Budějovicích zůstane spíše osamocen. Jak totiž judikoval Nejvyšší soud ČR, odborové organizace mají skutečně výjimečné postavení i z hlediska rejstř́kového řízení. Nejvyšší soud ve svých rozhodnutích projevil dostatečnou míru pochopení mezinárodních závazků České republiky a jistě si byl dobře vědom závěru č. 272 Digest, dle něhož překážky vzniku odborových organizací nesmí být takové povahy, která by se vyrovnala jejich zákazu. Dle závěru č. 275 a 276 Digest lze i v př́padě odborových organizací upravit formality, předepsané pro jejich vznik, nesmí však narušovat svobodu vzniku odborových organizací. Dle závěru č. 294 Digest by registrační ř́zení odborových organizací mělo být pouhou formalitou. A především dle závěru č. 302 Digest Výbor pro svobodu sdružování Správní rady Mezinárodní organizace práce věnuje pozornost tomu, zda v národní úpravě jsou dostatečně vyjasněny podmínky pro registraci odborových organizací.

Naprosto ve shodě se zmíněnými závěry a relevantní obavou z aplikačních problémů u nové právní úpravy Nejvyšší soud konstatoval: „Zápis odborové organizace do spolkového rejstřiku provede rejstřikový soud do 5 pracovnich dnů na základě oznámení o jejím založení, aniž by byl (mohl být) podán návrh na zápis do spolkového rejstř̌ku nebo by ve věci zápisu odborové organizace do spolkového rejstř́ku proběhlo (mohlo proběhnout) řizení podle Části třetí zákona č. 304/2013 Sb., o veřejných rejstř́cích fyzických a právnických osob (srov. § 121 odst. 2 a 3 zákona č. 304/2013 Sb., o veřejných rejstřícich fyzických a právnických osob).“41 Dle citovaného názoru se v případě zápisu odborové organizace tedy žádné řízení neprovádí. Pokud rejstř́ikový soud odborovou organizaci zapíše ve smyslu ust. § 121 odst. 1 ve spojení s ust. § 26 odst. 1 písm. a) zákona č. 304/2013 Sb., v platném znění, pak při současném stavu občanského soudního řádu lze najít stěží adekvátní názor, kterým by u již zapsané odborové organizace rejstř́kový soud mohl prosadit jeho změnu.

39 Usnesení Vrchního soudu v Olomouci ze dne 2. 8. 2016, sp. zn. 8 Cmo 232/2016.

40 Jmenovitě se jedná o ANO PRAZE, odbory pro hájení zaměstnanců Pražské služby, a.s., zapsaný spolek.

41 Usnesení Nejvyššího soudu ze dne 24. listopadu 2016, sp. zn. 21 Cdo 1917/2016. Srov. též usnesení Nejvyššího soudu ze dne 24. listopadu 2016, sp. zn. 21 Cdo 3520/2016 a Stanovisko občanskoprávního a obchodního kolegia Nejvyššího soudu ze dne 23. 4. 2014 k výkladu zastoupení účastníka občanského soudního ř́zení odborovou organizací. 
Pokud by rejstř́kový soud přesto v procesních předpisech našel adekvátní cestu, pak je nutno upozornit na existenci Úmluvy MOP č. 11 o svobodě sdružování v zemědělství, Úmluvy č. 87 a především čl. 27 odst. 2 Listiny základních práv a svobod. Posledně zmíněné ustanovení stanoví dva základní principy relevantní pro zkoumanou situaci. Zaprvé odborové organizace vznikají nezávisle na státu, tj. České republice. Zadruhé je nepřípustné, a to též pro rejstř́kové soudy, aby zvýhodňovaly některé odborové organizace v podniku nebo v odvětví. Jestliže tedy většina rejstř́kových soudů nepovažuje za klamavý název odborové organizace, který kromě slov odborová organizace obsahuje též slovo spolek, pak nemůže legitimně jeden z těchto soudů znevýhodnit odborové organizace, které žádají o zápis $\mathrm{v}$ jeho působnosti a klást na ně těžší požadavky než ostatní rejstř́kové soudy.

\section{ZÁVĚR}

Zákonné uchopení vzniku a právního jednání odborové organizace je vždy velmi citlivou politickou záležitostí, a to zejména z hlediska mezinárodních závazků České republiky. Jak totalitní, tak demokratické Československo v minulosti raději podvakrát ustoupilo (nejprve zákonem č. 74/1973 Sb., posléze zákonem č. 300/1990 Sb.), než aby čelilo námitkám ohledně porušování mezinárodních závazků souvisejících s koaliční svobodou. Odhlédneme-li od politických dobových reálií, pak jsou obě změny př́iznačné pro současnou situaci. $V$ prvém případě byl opuštěn formální (ROH bylo již dávno integrováno do státního organismu) povolovací režim i úprava fungování dobrovolných organizací, v druhém případě byla urychleně přijata specifická volnější úprava odborových organizací, ač obecný režim podle úmyslu zákonodárce čistě povolovací povahu mít neměl. Pro nedostatek dobových materiálů nevíme, zda raději zákonodárce novelizoval zákon o sdružování občanů dříve, než začal formálně platit též pro odborové organizace, spíše z obav před aplikační praxí či z mezinárodních sankčních mechanismů.

Stejně tak lze i v posuzovaném případě uzavř́ít, že Krajský soud v Českých Budějovicích nejspíše ustoupí praxi jiných rejstř́kových soudů a nebude masově nutit nové odborové organizace, aby se za spolek nepovažovaly. I nadále tak bude především na odborové organizaci, aby si rozhodla, zda její název by měl současně obsahovat v názvu slovo „spolek“, slova „zapsaný spolek“ či zkratku z. s. Takový postup sice není ideální, je však souladný jak s Listinou základních práv a svobod, tak s mezinárodními závazky České republiky. Kromě právní úpravy tomu nasvědčují citovaná rozhodnutí Nejvyššího soudu ČR i rozhodovací praxe obou vrchních soudů, jež dostatečně berou na zřetel smysl odborových organizací, způsob jejich vzniku i zákaz znevýhodňovat některé odborové organizace.

doc. JUDr. Martin Štefko, Ph.D.

Právnická fakulta Univerzity Karlovy

stefkom@prf.cuni.cz 